\title{
Pemerolehan Partikel Bahasa Jepang Pembelajar Siswa SMA
}

\author{
Assifa Gunawan Putri*, Dewi Kusrini, Ahmad Dahidi \\ Departemen Pendidikan Bahasa Jepang, Universitas Pendidikan Indonesia \\ Jl. Dr. Setiabudhi No. 229, Bandung 40154, Indonesia \\ *e-mail: assifagunawan@gmail.com
}

\begin{abstract}
Abstrak
Penelitian ini bertujuan untuk mengetahui seberapa banyak siswa yang dapat menguasai partikel level dasar bahasa Jepang, pemerolehan partikel level dasar apa saja yang paling dikuasai oleh siswa dan faktor apa saja yang menyebabkan kurangnya pemerolehan siswa dalam menguasai partikel level dasar bahasa Jepang. Dalam penelitian ini digunakan metode penelitian deskriptif. Instrumen yang digunakan berupa tes untuk mengetahui kemampuan siswa dalam menguasai pertikel level dasar bahasa Jepang dan angket untuk mengetahui faktor penyebab kesalahan siswa. Sampel dalam penelitian ini adalah siswa SMA kelas 1 dan 2 dari 3 sekolah yang berjumlah 150 siswa. Berdasarkan hasil analisa pada data terkumpul, diketahui bahwa dengan patokan lebih dari $45 \%$ dianggap "dapat menguasai", maka siswa yang dapat menguasai partikel level dasar adalah 32,87\% dan siswa yang tidak dapat menguasai partikel level dasar adalah $67,13 \%$. Urutan partikel yang dapat dikuasai siswa dari yang paling mudah ke yang paling sulit adalah $[\mathrm{Wa}>\mathrm{Ga}>\mathrm{He}>\mathrm{De}>\mathrm{Ni}>\mathrm{No}>\mathrm{Mo}>\mathrm{To}>\mathrm{Wo}$. Faktor penyebab kesalahan siswa dalam menggunakan partikel tersebut adalah siswa kesulitan mengingat fungsi partikel dan kurang mengerti secara detail terkait setiap fungsi partikel yang dipelajari. Dari hasil penelitian yang telah dilakukan, diperlukan adanya penjelasan lebih mendetail terkait fungsi setiap partikel bahasa Jepang dalam buku ajar yang digunakan dan penjelasan di kelas untuk meminimalisir kebingungan siswa mengenai penggunaan partikel dalam kalimat bahasa Jepang, serta diperlukannya kegigihan siswa dalam mengingat kembali partikel yang telah dipelajari.
\end{abstract}

Kata Kunci: pemerolehan bahasa Jepang; partikel dasar bahasa Jepang; fungsi partikel; siswa SMA

\begin{abstract}
This research discusses acquisition of basic particles which had learned by high school students. The purpose is to find how many students who understand basic particles of Japanese language, to find which particles they understand and to find any factor caused the lack of understanding to utilize the basic particles of the Japanese language. Description method is used in this research. The instrument is a questionnaire and a test. The sample is the first and the second year high school students numbered 150 from 3 different high schools in Bandung city. According to score standard, it is known that students whose score is above $45 \%$ are considered understand. And the result of data analysis showed that $32,07 \%$ of students understand and $67,13 \%$ of students do not understand. The sequence from the easiest to the hardest basic particles understand by students are $[W a>G a>H e>D e>N i>N o>M o>T o>W o]$. The factor that caused the lack of understanding to utilize the basic particles is the difficulty of remembering the function of particles and not to understand the detail of every function basic particles which had learned. From the result of research, the writer makes an assumption which is needed for more detail explanation related to every function basic particles in order to minimalize confusion of student to utilize to utilize the basic particles of the Japanese language. Also, needed for the persistence of students in remembering all function basic particles which had learned.
\end{abstract}


Keywords: japanese language acquisition; japanese particles, particles function, high school students.

\section{PENDAHULUAN}

Partikel dalam bahasa Jepang jumlahnya cukup banyak dan fungsinya bermacam-macam. Misalnya partikel De dalam kasus tertentu, artinya dapat disamakan dengan partikel Wo dan partikel $N i$. Berdasarkan hasil pengamatan dan pengalaman penulis selama 4 bulan kegiatan ppl, pembelajar siswa SMA sering keliru karena penggunaan pertikel yang banyak macamnya, sehingga siswa tampak kebingungan dalam penempatannya. Lalu penempatan partikel yang tidak tepat dapat mempengaruhi makna kalimat yang dimaksud. Perbedaan-perbedaan dalam mengartikan partikel menjadi salah satu kesulitan yang dihadapi dalam mempelajari bahasa Jepang. Di bawah ini adalah contoh kerangka kalimat yang dipelajari siswa dalam mempelajari bahasa Jepang:

$($ tempat $)+($ partikel de $)+($ benda $)+($ partikel wo) + (kaimashita).

(1) Ichiba de yasai wo kaimashita.

Membeli (lampau) sayuran di pasar.

Dari contoh di atas diketahui bagaimana siswa SMA mempelajari suatu kalimat dalam bahasa Jepang yaitu pertama, diberi kerangka pola kalimat lalu kedua, diberi contoh pola kalimat dan akhirnya berdasarkan kerangka dan contoh tersebut siswa dapat belajar untuk membuat kalimat bahasa Jepang yang utuh. Walaupun siswa dapat mengerti suatu kalimat bahasa Jepang yang lengkap dengan adanya subjek, objek, keterangan tempat dan waktu, begitu dihadapkan dengan soal perintah melengkapi partikel, siswa masih banyak mengalami kesalahan. Hal ini membuktikan siswa kurang memahami penempatan dan fungsi setiap partikel yang telah dipelajari.

Contoh soal melengkapi partikel:

(2) Zubon wa sangai .... arimasu.

Celana panjang ada....lantai tiga.

Terkait soal di atas banyak siswa yang menjawab $W a$ sementara jawaban yang benar adalah Ni. Sehingga koreksi jawaban siswa dari contoh soal (2) adalah sebagai berikut.

(3) Zubon wa sangai ni arimasu. celana panjang ada di lantai tiga.

Berdasarkan latar belakang yang telah dipaparkan sebelumnya, penulis ingin meneliti sejauh mana siswa SMA dapat menempatkan partikel yang tepat dalam suatu konteks kalimat agar dapat menjadi kalimat yang dipahami lawan bicara. Bagaimana urutan pemerolehan partikel dasar tersebut serta faktor apa yang menyebabkan siswa sulit untuk menguasai partikel level dasar tesebut.

Masalah yang akan berusaha dipecahkan pada penelitian ini adalah sebagai berikut :

1. Seberapa banyak siswa yang dapat menguasai partikel level dasar bahasa Jepang?

2. Pemerolehan partikel apa saja yang mudah dan sulit dikuasai siswa? 
JAPANEDU: Jurnal Pendidikan dan Pengajaran Bahasa Jepang

Vol. 2, No. 2, Desember 2017, pp. 153-167

3. Faktor apakah yang menyebabkan menyajikan materi yang sudah dipahami. Ciri-

kurangnya pemerolehan siswa dalam

menguasai partikel level dasar?

Dari permasalahan yang telah dipaparkan sebelumnya, maka tujuan dari penelitian ini adalah :

1. Untuk mengetahui seberapa banyak siswa yang dapat menguasai partikel level dasar bahasa Jepang.

2. Untuk mengetahui pemerolehan partikel apa saja yang paling dikuasai siswa.

3. Untuk mengetahui faktor apakah yang menyebabkan kurangnya pemerolehan siswa dalam menguasai partikel level dasar.

\section{Kajian Teoritis}

Pemerolehan bahasa kedua (B2) dimaknai saat seseorang memperoleh bahasa lain setelah terlebih dahulu ia menguasai sampai batas tertentu bahasa $\cup$ ibu $\llcorner$ (B1). Menurut Solehan (2011: 26) bahasa kedua adalah bahasa yang dikuasai anak setelah menguasai bahasa pertama. Sedangkan menurut Abdul Chaer dan Agustina (2004: 82) bahasa lain yang bukan bahasa ibunya yang dipelajari seorang anak disebut bahasa kedua.

Dalam memperoleh bahasa kedua banyak cara yang dapat dilakukan. Krashen dan Terrel (dalam Akhadiah, dkk, 1997: 25) membagi dua tahap pemerolehan bahasa kedua yaitu pemerolehan bahasa kedua secara terpimpin dan pemerolehan bahasa kedua secara alamiah.

Pemerolehan bahasa kedua secara terpimpin, berarti pemerolehan bahasa kedua yang diajarkan kepada pelajar dengan 
kedua dilakukan secara rapi atau sistematis sebagai aktivitas belajar. Oleh karena itu, bahasa kedua diperoleh dengan pembelajaran.

Menurut Matsumura (1998:65) partikel adalah salah satu kelas kata dalam bahasa Jepang. Partikel tidak dapat berdiri sendiri atau dan tidak mengalami perubahan. Partikel dipakai untuk menunjukan hubungan antara kata tersebut dengan kata lain serta untuk menambah arti kata tersebut lebih jelas lagi. Hayashi (1990:470) dalam teorinya menjelaskan tentang partikel adalah jenis kata yang penting yang menjadi tiang sebuah kalimat, bersama dengan kata kerja bantu.

Tadasu (1989 : 157) menyebutkan partikel masuk ke dalam kelompok fuzokugo, karena tidak dapat berdiri sendiri membentuk bunsetsu.

Dalam mempelajari Bahasa Jepang siswa SMA dituntut untuk dapat menguasai kalimat bahasa Jepang. Di dalam kalimat tersebut terdapat partikel sebagai penyambung kalimat. Partikel level dasar bahasa Jepang yang diajarkan pada siwa SMA adalah $W a$, Wo, Ni, De, Ga, To, No, Mo, dan He. Untuk mengajarkan kalimat dan partikel level dasar tersebut, banyak guru SMA yang menggunakan Buku Pelajaran Bahasa Jepang Sakura 1 dan 2 yang ditulis sebagai sumber ajar.

Adapun penelitian yang berhubungan dengan partikel bahasa Jepang dengan responden orang Vietnam adalah penelitian yang telah dilakukan oleh Van Anh (2013). Penelitian tersebut meneliti bagaimana tingkat kemahiran mahasiswa Vietnam menggunakan partikel ni, de, dan wo dalam sebuah kalimat. diketahui hasil secara keseluruhan bahwa kemahiran bahasa pertama (Vietnam) bisa diterapkan ke dalam kemahiran penggunaan partikel bahasa kedua (Jepang). Lalu, pada prosesnya penelitian ini menunjukan adanya perkembangan kata benda dan kata kerja bahasa kedua. Namun, dalam hasil penelitian ini tidak terfokuskan pada partikel melainkan condong kearah penerapan bahasa kedua (Jepang) kedalam bahasa pertama (Vietnam).

\section{METODE}

Penelitian ini menggunakan metode deskriptif kuantitatif. Expulasi ${ }^{8-5}$ dalam penelitian ini adalah siswa SMA dari 3 SMA yang berbeda di Bandung. Sampel penelitian ini berjumlah 150 siswa diambil dari siswa kelas 1 10-11 masing-masing diambil dari 50 siswa setiap sekolah. Siswa-siswa tersebut telah mempelajari materi yang sama dan berasal dari sumber ajar yang sama pula, yaitu

\section{Buku Pelajaran Bahasa Jepang Sakura.}

Instrumen yang digunakan dalam penelitian ini adalah tes dan angket. Tes disusun setelah penulis memastikan materi apa saja yang telah dipelajari siswa SMA. Penulis menemukan 14 fungsi dari 9 partikel yang berasal dari Buku Pelajaran Bahasa Jepang Sakura.Sembilan partikel tersebut antara lain adalah partikel Wa, Wo, Ni, De, Ga, To, No, Mo, dan $\mathrm{He}$.

Untuk menguji pamahaman siswa terhadap penggunaan pertikel level dasar, 
JAPANEDU: Jurnal Pendidikan dan Pengajaran Bahasa Jepang

Vol. 2, No. 2, Desember 2017, pp. 153-167

penulis memutuskan untuk membuat dua macam soal yaitu soal dengan kosakata yang ada di buku sakura dan soal dengan kosakata yang tidak ada di buku sakura. Hal ini dilakukan untuk mengetahui siswa menjawab soal apakah karena benar-benar memahami penggunaan fungsi partikel atau karena mengenali kosakata yang telah dipelajari sebelumnya.

Berdasarkan paparan di atas, penulis membuat 56 soal tes tertulis, yang terdiri atas 14 fungsi partikel. Setiap fungsi partikel memiliki 4 soal, 2 soal dengan kosakata dari buku sakura dan 2 soal lainnya dengan kosakata di luar buku sakura.

Dalam penelitian ini jenis angket yang digunakan adalah angket terbuka. Angket terbuka merupakan jenis angket yang memberikan keleluasaan bagi responden untuk menyampaikan pendapatnya.

Penulis membagi isian angket menjadi dua bagian yaitu bagian $\mathrm{A}$ dan bagian $\mathrm{B}$. Bagian A isian yang digunakan adalah essay bertujuan untuk mengetahui alasan siswa merasa kesulitan dalam menguasai partikel yang telah diajarkan, sedangkan pada angket bagian $\mathrm{B}$ isian yang digunakan adalah pilihan ganda yang terdiri atas pilihan sangat setuju (SS), setuju (S), tidak setuju (TS), dan sangat tidak setuju (STS) untuk mengetahui faktor apa saja yang membuat siswa kesulitan menguasai partikel.

Pengolahan data yang digunakan pada penelitian ini yaitu teknik pengolahan data tes dan teknik pengolahan data angket. Tujuan utama pengolahan data tes adalah untuk mengetahui tingkat pemahaman siswa SMA terhadap partikel level dasar dengan melakukan langkah-langkah berikut ini :

1. Menghitung jumlah jawaban tes.

2. Menghitung presentase jawaban tes dengan rumus berikut ini:

3. Menghitung skor mentah dan skor standar jawaban tes.

4. Menghitung tingkat penggunaan partikel level dasar.

5. Menghitung tingkat kesalahan partikel level dasar.

Dan tujuan utama pengolahan data angket adalah untuk mengetahui faktor kesulitan siswa SMA terhadap partikel level dasar dengan melakukan langkah-langkah berikut ini :

1. Mengklarifikasikan jawaban angket.

2. $E$ Menghitung $\leftrightarrow$ presentase dari setiap jawaban angket.

3. Menafsirkan data angket dan menginterpretasi jawaban siswa.

\section{HASIL DAN PEMBAHASAN}

Berikut adalah paparan hasil tes dan angket terhadap 150 siswa SMA terkait memperoleh penguasaan partikel level dasar bahasa Jepang yang telah diajarkan sebelumnya.

\section{Partikel Ga}

Berikut ini soal-soal dengan partikel ga sebagai jawaban yang benar dalam tes yang diberikan pada siswa 
Assifa Gunawan Putri, Dewi Kusrini, Ahmad Dahidi, Pemerolehan Partikel Bahasa Jepang

Pembelajar siswa SMA

-3- Uchi ni terebi___ arimasu
a. de
b. he
c. ga
d. wo

-4- Otouto rokunin imasu.
a. to
b. he
c. wo
d. ga

-32- Ane __ gonin imasu
a. wo
b. ga
c. ni
d. he

-17- Uchi ni kaidan (tangga) __ arimasen
a. de
b. wo
c. ga
d. no

-31- Heya ni kutsu arimasu
a. de
b. no
c. to
d. ga

-18- Itoko (sepupu laki-laki) _ yonin imasu
a. de
b. wo
c. he
d. ga

-45- Heya ni fukuro (dompet)__arimasu
a. he
b. ga
c. wo
d. de

-46- Tsuma (istri) __ futari imasu
a. ga
b. wo
c. he
d. to

Secara keseluruhan kemampuan siswa dalam memahami partikel ga berdasarkan hasil tes adalah sebagai berikut: jawaban siswa terhadap soal nomor 3, 4, dan 32 termasuk kategori 'lebih dari cukup'. Soal nomor 17, 31, 45, 18 dan 46 termasuk kategori 'cukup rendah'. Dan tidak ada jawaban siswa yang termasuk kategori 'rendah'.

Pada delapan soal yang berkaitan dengan partikel ga, presentase siswa yang menjawab partikel ga lebih tinggi dibandingkan presentase siswa yang menjawab partikel selain ga.

Penulis berasumsi pada partikel siswa sudah banyak menjawab benar terhadap soal yang mengandung kosakata yang ada di buku Sakura maupun yang tidak ada, namun ada beberapa siswa lainnya yang mungkin terlupa atau tidak sepenuhnya memahami mengenai penggunaan fungsi-fungsi partikel ga yang telah diajarkan.

\section{Partikel De}

Berikut ini soal-soal dengan partikel de sebagai jawaban yang benar dalam tes yang diberikan pada siswa

-5- Jasmin san wa resutoran __ gohan wo tabemasu.
a. de
b. wo
c. ni
d. wa

-6- Zaidan san wa mainichi kuruma gakkou he ikimasu.
a. he
b. wa
c. de
d. wo

-19- Ashita Gedung Sate __ hyouji shimasen ( tidak berdemo)
a. wo
b. de
c. ni 
d. wa

-20- Ankooto (angkot) uchi he kaerimasu
a. de
b. wo
c. he
d. wa

-33- Kinou ichiba kaimono shimashita
a. no
b. ni
c. de
d. to

-34- Senshuu haha wa takushi uchi he

kaerimashita
a. de
b. ni
c. no
d. to

-47- Maato (mart)___tomodachi to hanashi wo shimasu
a. wa
b. wo
c. ni
d. de

-48- Kyounen (tahun lalu) jinrikisha (beca) umi he ikimashita
a. wo
b. ni
c. de
d. wa

Secara keseluruhan kemampuan siswa dalam memahami partikel de berdasarkan hasil tes adalah sebagai berikut: jawaban siswa terhadap soal nomor 6, 20, dan 34 termasuk kategori 'lebih dari cukup'. Soal nomor 5, 19, dan 33 termasuk kategori 'cukup rendah'. Dan jawaban siswa terhadap soal nomor 47 dan 48 termasuk kategori 'rendah'.

Pada soal-soal fungsi de tersebut, presentase siswa yang menjawab jawaban benar lebih tinggi dibandingkan presentase siswa yang menjawab pilihan selain de. Kecuali untuk soal nomor 47 dan 48, di nomor
47 siswa lebih banyak menjawab pilihan wa (36\%) dan di nomor 48 siswa lebih banyak menjawab pilihan ni $(30,6 \%)$.

Penulis berasumsi kesulitan siswa menjawab soal nomor 47 dan 48 adalah karena menggunakan kosakata yang tidak ada di buku Sakura dan tidak dikenal siswa sebelumnya. Walau begitu, pada soal nomor 19 dan 20 yang juga tidak menggunakan kosakata yang ada di buku Sakura, bisa dijawab oleh siswa bahkan menjadi soal dengan presentase jawaban benar paling tinggi terkait fungsi-fungsinya.

\section{Partikel Wo}

Berikut ini soal-soal dengan partikel wo sebagai jawaban yang benar dalam tes yang diberikan pada siswa

$$
\begin{aligned}
& \text {-1- Asa eiga __ mimasendeshita. } \\
& \text { a. wo wAHASA JEPANG } \\
& \text { b. wa } \\
& \text { c. ni } \\
& \text { d. to } \\
& \text {-2- Ocha } \\
& \text { a. ni } \\
& \text { b. wo } \\
& \text { c. wa } \\
& \text { d. to }
\end{aligned}
$$

-15- Watashi wa yuube (tadi malam) ni shosetsu (novel) __ yomimashita.
a. ni
b. wa
c. wo
d. to

-16- Takoyaki ___ mittsu kudasai
a. wo
b. ga
c. wa
d. he 
-29- Watashi wa maiban (setiap malam) ni

$$
\begin{array}{ll}
\text { a. } & \text { ga } \\
\text { b. wo } \\
\text { c. wa } \\
\text { d. to }
\end{array}
$$$$
\text { shawaa__abimasu (mandi) }
$$

-30- Kaban hitotsu kudasai
a. wo
b. he
c. ga
d. wa

-43- Senshuu sensei to kageki (opera)

mimasu
a. to
b. wa
c. ni
d. wo

-44- Arubamu (album)___ hitotsu kudasai
a. wa
b. he
c. ga
d. wo

Secara keseluruhan kemampuan siswa dalam memahami partikel wo berdasarkan hasil tes adalah sebagai berikut: jawaban siswa terhadap soal nomor 1 termasuk kategori 'lebih dari cukup'. Soal nomor 15 dan 43 termasuk kategori 'cukup rendah'. Dan jawaban siswa terhadap soal nomor 29, 2, 16, 30, dan 44 termasuk kategori 'rendah'.

Pada fungsi partikel wo yang menyatakan objek/ tujuan kata kerja transitif, siswa menjawab benar paling tinggi pada soal dengan kosakata yang ada di buku Sakura, namun menjawab benar terendah juga ada pada soal yang menggunakan kosakata yang ada di buku Sakura.

Penulis berasumsi hal tersebut dikarenakan kosakata 'shawa wo abimasu' tidak begitu dipahami siswa walau termasuk dalam materi yang telah diajarkan di sekolah.

Pada fungsi partikel wo yang menunjukan minat/ keinginan, penulis berasumsi siswa kurang hafal sebutan satuan bahasa Jepang seperti nihai, hitotsu, issatsu, dan mittsu. Walau begitu kelihatannya siswa cukup akrab dengan kosakata 'Takoyaki' yang merupakan makanan Jepang yang juga banyak dijual di sekitar sekolah.

\section{Partikel Ni}

Berikut ini soal-soal dengan partikel ni sebagai jawaban yang benar dalam tes yang diberikan pada siswa

-7- Resutoran gohan ga arimasu.
a. no

b. wa

c. to

d. ni

-8- Eren san wa tomodachi aimasu
a. ga
b. ni
c. de
d. mo

-9- Maiasa rokuji okimasu (bangun).
a. no
b. to
c. ni
d. wa

-21- Anata no apaato (apartment) wa doko arimasuka
a. he
b. no
c. to
d. ni

-22- Otto (suami) aimasu
a. ga
b. de
c. he
d. ni 
-23- Watashi wa nichiyoubi __ yoku

aisusukeeto shimasu (ice skating)
a. to
b. ni
c. no
d. he

-35- Kamera wa ikkai ___ arimasu
a. ni
b. to
c. no
d. wa

-36- Watashi wa Tanaka san__aimasen
a. ga
b. ni
c. de
d. wa

-37- Chichi wa mokuyoubi__amari

sanpoushimasen
a. wa
b. to
c. no
d. ni

-49- Dedi san wa Rini san no tonari __ imasu
a. to
b. ni
c. no
d. wa

-50- Kesa (tadi pagi) kosupureiyaa

(cosplayer)__aimashita
a. he
b. de
c. ni
d. ga

-51- Asa hachiji__yoku kakurenbo wo shimasu (petak umpat)
a. ni
b. to
c. no
d. he

Secara keseluruhan kemampuan siswa dalam memahami partikel ni berdasarkan hasil tes adalah sebagai berikut: jawaban siswa terhadap soal nomor 21,49 , dan 8 termasuk kategori 'lebih dari cukup'. Soal nomor 35, 36,
9, 23, 37, dan 51 termasuk kategori 'cukup rendah'. Dan jawaban siswa terhadap soal nomor 7, 22, dan 50 termasuk kategori 'rendah'.

\section{Partikel Wa}

Berikut ini soal-soal dengan partikel wa sebagai jawaban yang benar dalam tes yang diberikan pada siswa

-10- Anata __ nansai desuka.
a. wa
b. he
c. wo
d. de

-24- Reina san __ naasu (perawat) desu
a. de
b. wo
c. wa
d. he

-38-Watashi no ani__ gunjin (tentara) desu
a. wo
b. de
c. wa
d. ni

-52-Watashi no namae___Yahya desu
a. de
b. wo
c. he
d. wa

Presentase siswa yang menjawab partikel wa lebih tinggi dibandingkan presentase siswa yang menjawab partikel selain wa.

Dilihat dari hal tersebut, secara keseluruhan kemampuan siswa dalam memahami partikel wa berdasarkan hasil tes adalah sebagai berikut: jawaban siswa terhadap soal nomor 10 dan 24 termasuk kategori 'lebih dari cukup'. Soal nomor 38

\section{E-ISSN: 2528-5548}


dan 52 termasuk kategori 'cukup rendah'. Dan tidak ada jawaban siswa yang termasuk kategori 'rendah'.

\section{Partikel No}

Berikut ini soal-soal dengan partikel no sebagai jawaban yang benar dalam tes yang diberikan pada siswa

$\begin{array}{rr}\text {-12- Kore wa } \\ \text { a. } & \text { ni } \\ \text { b. } & \text { no } \\ \text { c. } & \text { de } \\ \text { d. } & \text { ga }\end{array}$

-26- Kore wa Abi Bayu san ___ petto (peliharaan) desu
a. ni
b. ga
c. no
d. he

-40- Anata __ oshigoto wa nandesuka
a. ni
b. ga
c. no
d. wo

-54- Anohito wa watashi__koibito (pacar) desu
a. de
b. he
c. no
d. ni

Dilihat dari hal ini, secara keseluruhan kemampuan siswa dalam memahami partikel no berdasarkan hasil tes adalah sebagai berikut: jawaban siswa terhadap soal nomor 12 termasuk kategori 'lebih dari cukup'. Soal nomor 54 termasuk kategori 'cukup rendah'. Dan jawaban siswa terhadap soal nomor 26 dan 40 termasuk kategori 'rendah'.

Pada empat soal yang berkaitan dengan partikel no, siswa lebih memahami soal dengan kosakata yang telah dipelajari sebelumnya (kosakata yang ada di buku Sakura).

\section{Partikel Mo}

Berikut ini soal-soal dengan partikel mo sebagai jawaban yang benar dalam tes yang diberikan pada siswa

-14- Kyou wa doko ikimasen
a. mo
b. no
c. de
d. ni

-28- Otouto wa kinou nani shimasendeshita
a. de
b. mo
c. no
d. ni

-42- Ani wa ototoi (lusa kemarin) doko ikimasendeshita

a. de

b. no

c. mo

d. ni

-56- Anata wa kyou wa nani shimasen
a. no
b. ni
c. de
d. mo

Pada empat soal yang berkaitan dengan partikel mo, siswa lebih memahami soal dengan kosakata yang telah dipelajari sebelumnya (kosakata yang ada di buku Sakura).

Dilihat dari hal ini, secara keseluruhan kemampuan siswa dalam memahami partikel mo berdasarkan hasil tes adalah sebagai berikut: Soal nomor 14, 56, dan 28 termasuk kategori 'cukup rendah'. Dan jawaban siswa 
terhadap soal nomor 42 termasuk kategori 'rendah'.

\section{Partikel $\mathrm{He}$}

Berikut ini soal-soal dengan partikel he sebagai jawaban yang benar dalam tes yang diberikan pada siswa

-11- Luffy san wa mainichi uchi kaerimasen.
a. ga
b. no
c. to
d. he

-25- Kinou PVJ mooru (Paris Van Java Mall) ikimashita
a. he
b. ni
c. wo
d. wa

-39- Ototoi yuubinkyouku___kimashita
a. ga
b. he
c. to
d. no

-53- Yoru kazoku to inaka (desa)___ikimasu
a. no
b. he
c. to
d. wo

Pada empat soal yang berkaitan dengan pertikel he, siswa lebih memahami soal dengan kosakata yang belum dipelajari sebelumnya, namun diterangkan artinya (kosakata yang tidak ada di buku Sakura).

Dilihat dari hal tersebut, secara keseluruhan kemampuan siswa dalam memahami partikel he berdasarkan hasil tes adalah sebagai berikut: Soal nomor 25 termasuk kategori 'cukup tinggi'. Jawaban siswa terhadap soal nomor 53 termasuk kategori 'lebih dari cukup'. Jawaban siswa terhadap soal nomor 39 termasuk kategori 'cukup rendah'. Dan, jawaban siswa terhadap soal nomor 11 termasuk kategori 'rendah'.

Soal nomor 25 mengenai partikel he ini adalah soal dengan presentase jawaban benar tertinggi diantara 55 soal lainnya, bahkan termasuk ke dalam kategori 'cukup tinggi' . Kategori ini adalah satu-satunya diantara 56 soal yang dibagikan pada siswa, sedangkan rata-ratanya adalah kategori 'lebih dari cukup', 'cukup rendah', dan 'rendah'.

\section{Partikel To}

Berikut ini soal-soal dengan partikel to sebagai jawaban yang benar dalam tes yang diberikan pada siswa

-13- Maishuu tomodachi sakkaa wo shimasu.

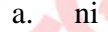

b. to

c. wo

d. he

-27- Amari Mimi Peri-san bare (ballet) wo shimasen
a. to
b. ni
c. wo
d. he

-41- Watashi wa kinou kazoku __oyogimashita
a. ni
b. wo
c. to
d. he

-55- Kyoushitsu de Nunung san___ jyoudan shimasu (bercanda)
a. ni
b. wo
c. he
d. to 
Pada empat soal yang berkaitan dengan partikel to, siswa lebih memahami soal dengan kosakata yang telah dipelajari sebelumnya (kosakata yang ada di buku Sakura).

Dilihat dari hal ini, secara keseluruhan kemampuan siswa dalam memahami partikel Toberdasarkan hasil tes adalah sebagai berikut: Soal nomor 41 dan 13 termasuk kategori 'cukup rendah'. Dan jawaban siswa terhadap soal nomor 27 dan 55 termasuk kategori 'rendah'.

Berdasarkan hasil analisis dan pembahasan tes, diketahui presentase setiap partikel menjadi patokan penulis untuk mengukur partikel mana saja yang dikuasai siswa dan mana saja yang tidak dikuasai siswa. Rincian rumus yang digunakan penulis adalah :

$\mathrm{M}=$ jumlah seluruh data

Banyak data

Sesuai rumus statistik di atas, penulis mendapatkan rata-rata partikel Wo adalah $29,36 \%$, rata-rata partikel $G a$ adalah $42,7 \%$, rata-rata partikel $D e$ adalah $37,18 \%$, rata-rata partikel $N i$ adalah $36,15 \%$, rata-rata partikel $\mathrm{Wa}$ adalah 49,97, rata-rata partikel $\mathrm{He}$ adalah $41,65 \%$, rata-rata partikel $N o$ adalah $35,65 \%$, rata-rata partikel To adalah $29,85 \%$, dan ratarata partikel $M o$ adalah 29,97\%. Berdasarkan hal tersebut, urutan partikel level dasar bahasa Jepang yang dikuasai siswa SMA dari yang paling mudah dipahami ke yang paling sulit dipahami adalah partikel $\mathrm{Wa}>\mathrm{Ga}>\mathrm{He}>\mathrm{De}$ $>N i>N o>M o>T o>$ Wo.
Penghitungan skor mentah dan skor standar :

Hasil penjumlahan keseluruhan skor mentah $=2.948$

Hasil penjumlahan keseluruhan skor standar $=4930.88$

Berdasarkan penafsiran data menggunakan standar penilaian, tingkat kesalahan siswa termasuk dalam kategori cukup tinggi $(67,13 \%)$. Dilihat dari hal ini presentase tingkat kemampuan rata-arata siswa dalam mengerjakan partikel level dasar adalah 32,87\% (cukup rendah). Penulis mendapatkan jawaban untuk rumusan masalah yang menjadi patokan dalam berlangsungnya penelitian, berikut ini rumusan masalah dan jawaban yang penulis dapatkan.

1. Seberapa banyak siswa yang dapat menguasai partikel level dasar bahasa Jepang?

Berdasarkan penghitungan rata-rata jawaban siswa dalam analisis data tes, menghitung skor mentah dan merubah skor mentah menjadi skor standar, dan menggunakan rumus untuk menghitung presentase kemampuan dan kesalahan siswa, didapatkan bahwa dari tiga sekolah yang menjadi sampel, siswa yang menguasai penggunaaan partikel level dasar adalah $32,87 \%$ dengan penafsiran "cukup rendah" dan siswa yang tidak menguasai penggunaan partikel level dasar adalah 67,13\% dengan penafsiran "cukup tinggi".

Siswa dalam menjawab soal tes cenderung menjawab benar terhadap soal dengan kosakata yang mereka pahami, 
JAPANEDU: Jurnal Pendidikan dan Pengajaran Bahasa Jepang

Vol. 2, No. 2, Desember 2017, pp. 153-167

terlepas kosakata tersebut ada di dalam materi

(buku Sakura) atau pun tidak. Penulis berasumsi bahwa sebenarnya siswa cukup memahami setiap fungsi-fungsi partikel bahasa Jepang yang telah diajarkan dan siswa akan mengingat fungsi apa yang sesuai dengan suatu kalimat jika siswa tersebut memahami kosakata-kosakata yang ada di dalam kalimat tersebut. Namun, tidak hanya kosakata saja, pola kalimat pun kurang dipahami siswa. Hal ini terlihat dari siswa yang memang kesulitan melengkapi sebuah kalimat bahkan dengan menggunakan kosakata yang telah diajarkan.

2. Pemerolehan partikel apa saja yang paling dikuasai siswa?

Berdasarkan analisis setiap partikel, fungsi-fungsi partikel, analisis setiap jawaban siswa dari 56 soal, dan penghitungan rata-rata, urutan partikel yang dipahami siswa dari yang termudah ke tersulit adalah $\mathrm{Wa}>\mathrm{Ga}>\mathrm{He}>$ $\mathrm{De}>\mathrm{Ni}>\mathrm{No}>\mathrm{Mo}>\mathrm{To}>\mathrm{Wo}$. Pemerolehan partikel $W a$ adalah yang paling tinggi atau yang paling dikuasai oleh siswa, diikuti dengan partikel $\mathrm{Ga}, \mathrm{He}, \mathrm{De}, \mathrm{Ni}, \mathrm{No}$, Mo, To, kemudian pemerolehan partikel Wo adalah yang paling rendah atau yang paling tidak dikuasai oleh siswa.

3. Faktor apakah yang menyebabkan kurangnya pemerolehan siswa dalam menguasai partikel level dasar?

Faktor-faktor kurangnya pemahaman siswa dalam menguasai partikel bahasa Jepang adalah siswa tidak begitu paham secara mendetail mengenai fungsi partikel dikarenakan dalam materi yang diberikan dan buku ajar yang digunakan, memang tidak dijelaskan secara mendetail terkait fungsi setiap partikel.

Siswa pun mudah lupa mengenai kegunaan suatu partikel dalam kalimat yang sudah pernah dibahas di dalam kelas. Berdasarkan angket siswa mengaku aktif bertanya, bersemangat dan memperhatikan guru saat menjelaskan, guru pun telah menjelaskan secara mendetail dan banyak memberi latihan soal.

Dalam hasil angket, siswa mengaku bahwa mereka cukup sering menemui partikel bahasa Jepang dalam anime, film, dan buku Jepang tetapi hanya mengandalkan hasil belajar di sekolah terkait partikel bahasa Jepang. Penulis mengasumsikan bahwa siswa mengingat dan mempelajari partikel saat di sekolah saja dan tidak cukup memahami fungsi penggunaannya.

Saat di luar sekolah pun siswa tidak mencari referensi lain untuk mempelajari partikel bahkan saat tanpa sengaja menemui partikel dalam film atau buku Jepang, siswa tidak bermaksud untuk mempelajarinya (contoh: saat bermain game Jepang atau menonton film berbahasa Jepang).

\section{SIMPULAN}

Berdasarkan pembahasan hasil data tes dan angket yang dibahas di bab sebelumnya, kesimpulan penelitian ini adalah : 
1. Siswa yang menguasai penggunaaan partikel level dasar adalah "cukup rendah" (sesuai penafsiran) dan siswa yang tidak menguasai penggunaan partikel level dasar adalah "cukup tinggi" (sesuai penafsiran). Siswa dalam menjawab soal tes cenderung menjawab benar terhadap soal dengan kosakata yang mereka pahami, terlepas kosakata tersebut ada di dalam materi (buku Sakura) atau pun tidak.

2. Pemerolehan partikel $W a$ adalah yang paling tinggi atau yang paling dikuasai oleh siswa, diikuti dengan partikel $\mathrm{Ga}, \mathrm{He}, \mathrm{De}$, $\mathrm{Ni}$, No, Mo, To, kemudian pemerolehan partikel Wo adalah yang paling rendah atau yang paling tidak dikuasai oleh siswa.

3. Faktor kurangnya pemahaman siswa adalah siswa tidak begitu paham secara mendetail keseluruhan fungsi partikel dan mudah melupakan kegunaan suatu partikel dalam kalimat. Dalam pembelajaran bahasa Jepang, siswa aktif bertanya, bersemangat dan memperhatikan guru saat menjelaskan, guru pun telah menjelaskan secara mendetail dan banyak memberi latihan soal. Siswa juga cukup sering menemui partikel bahasa Jepang dalam anime, film, dan buku Jepang tetapi siswa tidak memanfaatkan sarana tersebut untuk mengingat kembali apa yang telah dipelajari di sekolah .

\section{PUSTAKA RUJUKAN}

[1] Akhadiah, dkk. 1997. Teori Belajar Bahasa. Jakarta: Universitas Terbuka
[2] Arifuddin. 2010. Neuropsikolinguistik. Jakarta: Raja Grafindo Persada

[3] Arikunto, Suharsimi. 2010. Prosedur Penelitian. Jakarta: Rineka Cipta.

[4] Cahyadi, Agung. 2015. Analisis Kemampuan Mahasiswa Dalam Menggunakan Partikel WO [Wo] Studi Deskriptif Terhadap Mahasiswa Departemen Pendidikan Bahasa Jepang FPBS UPI Tingkat III Tahun Ajaran 2014/2015. Skripsi Sarjana Pendidikan Bahasa Jepang, UPI Bandung : Tidak Diterbitkan.

[5] Chaer, Abdul. 2009. Psikolinguistik: Kajian Teoritik. Jakarta: PT. Rineka Cipta.

[6] Chaer, Abdul dan Leonie Agustina. 2004. Sosiolinguistik: Perkenalan awal. Jakarta: Rineka Cipta

[7] Departemen Pendidikan Nasional. 2008. Kamus Besar Bahasa Indonesia. Jakarta: PT Gramedia Pustaka Utama.

[8] Djardjowidjojo, Soejono. 2010. Psikolinguistik: Pengantar Pemahaman Bahasa Manusia. Jakarta: Yayasan Obor Indonesia.

[9] Hayashi, Ooki. 1990. Nihongo Kyouiku Handobukku. Tokyo: Taishuukan Shoten.

[10] Iwabuchi, Tadasu. 1989. Nihon Bunpou Yougo Jiten. Sanseido: Tokyo.

[11] Lusiana, Evi. 2009. Buku Pelajaran Bahasa Jepang 1 "Sakura". Jakarta: The Japan Foundation. 
[12] Lusiana, Evi. 2009. Buku Pelajaran

Bahasa Jepang 2 "Sakura". Jakarta:

The Japan Foundation.

[13] Punaji, Setyosari. 2010. Metode Penelitian Pendidikan dan Pengembangan. Jakarta : Kencana.

[14] Sudaryanto. 1993. Metode dan Aneka Tehnik Analisis Bahasa ( Pengantar Penelitian Wahana Kebudayaan secara Linguistik). Yogyakarta : Duta Wacana University Press.

[15] Solehan, dkk. 2011. Pendidikan Bahasa Indonesia. Jakarta: Universitas Terbuka

[16] Sudjianto, Ahmad Dahidi. 2004. Pengantar Linguistik Bahasa Jepang. Jakarta: Percetakan KBI.

[17] Sudjianto. 2000. Gramatika Bahasa Jepang Modern. Jakarta: Kesaint Blanc.

[18] Sugihartono. 2001. Partikel Bahasa Jepang. Bandung: Humaniora.

[19] Sutedi, Dedi. 2011. Penelitian Pendidikan Bahasa Jepang. Bandung: Humaniora.

[20] Tanaka, dkk. 2000. Minna no Nihongo I. Tokyo : 3A Corporation.

[21] Tarigan, Henry G. 2011. Pengajaran Pemerolehan Bahasa. Bandung: Angkasa.

[22] Universitas Pendidikan Indonesia. 2015. Pedoman Penulisan Karya Ilmiah. Bandung: UPI Press.

[23] Van Anh, Nguyen. 2013. ベチナム語 Wo 母語 $T o$ する日本語学習者 $N o$ 格 助詞 $N o$ 習得過程 $N i$ ついて一場所 $W o$ 表す格助詞 $\{N i\} \quad\{\mathrm{De}\} \quad\{\mathrm{Wo}\}$
$N o$ 場 合 一 。 Vietnam: Tidak

Diterbitkan.

[24] Wijayantiningrum, Dien. 2008. Analisis Kesalahan Mahasiswa Tingkat III Jurusan Pendidikan Bahasa Jepang UPI

Tahun Angkatan 2012/2013 Dalam Penggunaan Setsuzokushi Demo, Keredomo, Ga, dan Shikashi. Skripsi Sarjana Pendidikan Bahasa Jepang, UPI Bandung : Tidak Diterbitkan.

[25] Yamaguchi, Matsumura. 1998. Kokugo Jiten. Tokyo: Obunsha. 